IZA DP No. 6516

Certainty and Severity of Sanctions in Classical and Behavioral Models of Deterrence: A Survey

Horst Entorf

April 2012 


\title{
Certainty and Severity of Sanctions in Classical and Behavioral Models of Deterrence: A Survey
}

\author{
Horst Entorf \\ Goethe University Frankfurt \\ and IZA \\ Discussion Paper No. 6516 \\ April 2012 \\ IZA \\ P.O. Box 7240 \\ 53072 Bonn \\ Germany \\ Phone: +49-228-3894-0 \\ Fax: +49-228-3894-180 \\ E-mail: iza@iza.org
}

\begin{abstract}
Any opinions expressed here are those of the author(s) and not those of IZA. Research published in this series may include views on policy, but the institute itself takes no institutional policy positions.

The Institute for the Study of Labor (IZA) in Bonn is a local and virtual international research center and a place of communication between science, politics and business. IZA is an independent nonprofit organization supported by Deutsche Post Foundation. The center is associated with the University of Bonn and offers a stimulating research environment through its international network, workshops and conferences, data service, project support, research visits and doctoral program. IZA engages in (i) original and internationally competitive research in all fields of labor economics, (ii) development of policy concepts, and (iii) dissemination of research results and concepts to the interested public.
\end{abstract}

IZA Discussion Papers often represent preliminary work and are circulated to encourage discussion. Citation of such a paper should account for its provisional character. A revised version may be available directly from the author. 
IZA Discussion Paper No. 6416

April 2012

\section{ABSTRACT}

\section{Certainty and Severity of Sanctions in Classical and Behavioral Models of Deterrence: A Survey ${ }^{1}$}

This survey summarizes the classical fundamentals of modern deterrence theory, covers major theoretical and empirical findings on the impact of certainty and severity of punishment (and the interplay thereof) as well as underlying methodological problems, gives an overview of limitations and extensions motivated by recent findings of behavioral economics and discusses 'rational' deterrence strategies in subcultural societies.

JEL Classification: $\quad \mathrm{K} 4, \mathrm{HO}$

Keywords: economics of crime, behavioral economics, deterrence, survey

Corresponding author:

Horst Entorf

Goethe University Frankfurt

Department of Economics

Grüneburgplatz 1

60323 Frankfurt

Germany

E-mail: entorf@wiwi.uni-frankfurt.de

${ }^{1}$ Prepared for Springer Encyclopedia of Criminology and Criminal Justice.

The author is most grateful to Eirini Tatsi and Birgit Herrmann for helpful comments and suggestions. 


\section{Introduction.}

Severity of punishment without the credible threat of being detected and convicted ' $\ldots$ is the sound of one hand clapping'. ${ }^{2}$ Theoretical and empirical analyses of general deterrence need to consider both certainty and severity of sanctions, i.e. the intertwining activities of police, public prosecution, courts, and prison conditions representing the law enforcement system. Many studies only rely on the probability of detection, i.e. on police activity or efficiency, when discussing the role of 'expected' sanctions. Other studies, in particular articles dealing with U.S. data and thus motivated by the highly persistent upward trend in prisoner population, focus on the imprisonment rate and the severity of sanctions as crucial factors of deterrence (see the survey by Donohue, 2009). The (brief) survey at hand summarizes the classical rational-choice fundamentals of modern deterrence theory, covers major theoretical and empirical findings on the interplay of certainty and severity of punishment as well as important underlying methodological problems since the early 1970s of the last century.

Any survey of the economics of crime would be incomplete without reminiscence of recent developments in behavioral economics of crime. The last few years seem to have witnessed a change in mainstream economics of crime. Rational choice models are often criticized because they ignore that cognitive restrictions and emotional factors such as time pressure, peer group influence or anger restrict the long-run 'optimality' of individual decisions. Simon (1957) was the first to point out that the complexity of situations and limitations of both available information and cognitive capacity would lead to decisions under 'bounded rationality' rather than optimal ones, and humans are rather 'satisficers' seeking satisfactory solutions which make her or him happy enough. However, proponents of rational choice theory would argue that the underpinnings of Becker's (1968) general deterrence theory are still intact, for instance because the theory would not literally imply that would-be criminals weight all risks and costs at the very moment of a potential crime. Situational decisions under pressure could indeed be based on heuristics, rules of thumb and cognitive experience, but decision-making rules were developed and trained under trial-and-error situations over previous lifetime and under the prevailing maxim of individual long-run rationality. Thus, even under cognitive and emotional stress 'rationality may crystallize in the moment that a specific crime is contemplated' (Jacobs and Wright, 2010, p. 1741). Moreover, as suggested by Van Winden and Ash (2009), one might be tempted to conceptualize the cognitive component in economic crime models as an approximation of economically rational decision making. Nevertheless, several recent contributions focus on limitations and necessary extensions of the classical notion of certainty and severity of sanctions. This survey discusses significant insights stemming from behavioral economics such as impulsiveness (myopia),

\footnotetext{
${ }^{2}$ The original quote is 'Mediation without the credible threat of judicial determination is the sound of one hand clapping' (Genn, 2010, p.125, found in Thornburg, 2010).
} 
prospect theory, and anger. Moreover, stigma effects (dynamic deterrence) and the distinction between objective and perceived threats of potential punishment will be addressed.

This paper is organized as follows. Section 2 continues with a compact summary of classical deterrence theory and highlights the importance of expected sanctions. Section 3 provides a survey on theoretical and empirical results concerning the certainty of punishment, whereas Section 4 covers the literature on the severity of sentences. Section 5 focuses on limitations and extensions from behavioral economics, and Section 6 describes deterrence in subcultural and microstructural milieus without societal law enforcement systems. Section 7 concludes.

\section{Fundamentals of general deterrence theory.}

General deterrence is the avoidance of crime by (deterrable) potential offenders through the credible threat of punishment. This definition entails a) there is a threat in terms of a judicial system of appropriate sanctions, and b) this threat is credible, i.e. there is a legal enforcement system of police, prosecutors and judges which has the capability to realize a perceptibly high (strictly positive) probability of detection and conviction. The definition also requires that there is a non-empty group of compliers, i.e. a deterrable subgroup of the population which can be correctly described as 'potential offenders', because otherwise the theory of deterrence would be futile. The identification of 'deterrable' and 'non-deterrable' subpopulations is important but a rather neglected field in criminology (for remarkable exceptions, see Nagin and Paternoster, 1993; Pogarsky, 2002; Urban, 2009; and Ritchie, 2011). For example, Ritchie (2011) points at the significant impact of alcohol intoxication on the effectiveness of general deterrence.

The theoretical foundations of general deterrence are usually ascribed to Gary Becker's (1968) seminal article, although the philosophical foundation of deterrence dates back to 18th and 19th century and follows ideas by Beccaria (1819), Bentham (1830) and Chadwick (1829). In a broader sense, the idea of general deterrence is related to rational choice theory, which assumes that all individuals, irrespective of being criminal or not, respond to incentives, or as Becker puts it 'Some people become 'criminals' not because their basic motivation differs from that of other persons, but because their benefits and costs differ' (Becker, 1968, p. 176). Though often disputed and criticized (see, among many others, McAdams and Ulen, 2009, and Ritchie, 2011) the importance of rational choice and general deterrence has also been acknowledged by criminologists and sociologists: Economists should be given credit for one of the most exciting developments in research on deterrence in recent years. The techniques they used, the controversy they created and the discussions they 
generated have stimulated interest in deterrence research beyond all expectations (Fattah, $\left.1983^{3}\right)$.

Becker's theory ${ }^{4}$ on the supply of offenses is based on the comparison of (uncertain) expected utility $^{5}$ from criminal activities to the (relatively certain) utility from not committing crimes. Thus, increasing the individual 'costs' of crime by increasing the expected sentence would lead to a reduction of criminal behavior for rational offenders. Assuming additivity, the theory predicts that if the expected utility from committing a crime,

$$
E_{C}=(1-p) U_{C}+p\left(U_{C}-C_{C}\right)
$$

exceeds the expected utility from obeying the societal legal norms, $E_{N C}$, a crime will be committed, otherwise individuals refrain from wrongdoing. Here $p$ denotes the probability that the illegal act will be detected and punished, $(1-p)$ is the probability of getting away with it, $U_{C}$ represents utility from crime, $E_{N C}$ is utility from non-crime, and $C_{C}$ captures disutility (cost) from being punished. Obviously, to make punishment effective, $C_{C}$ needs to be higher than $U_{C}$. This condition fits Bentham's (1781) 'Principles of Morals and Legislation': According to Rule 1 of 'Of the Proportion between Punishments and Offences' 'The value of the punishment must not be less in any case than what is sufficient to outweigh that of the profit of the offence' (Bentham, 1781, p.141).

Equation (1) can be expressed as the difference between the benefit from committing a crime and the expected sentence in case of detection, i.e.

$$
E_{C}=U_{C}-p C_{C} .
$$

Equation (2) can be considered as the most parsimonious representation of severity and certainty of conviction. It is obvious that credibility of the threat of sanctions requires the expected sentence, i.e. product $p C_{C}$, to be positive. As an example of the deterrence rationale, consider the choice between paying a certain amount of money, say 3 Euros, for a short term city parking space, or not paying the amount and taking the risk of a fine of, say, 20 Euros. If on average every $10^{\text {th }}$ 'free parking' is detected, i.e. $p=0.1$, then the utility from

\footnotetext{
${ }^{3}$ Quotation found in Rupp (2008, p. 6).

${ }^{4}$ Actually, the main focus of Becker's (1968) article was to develop optimal public and private policies to combat illegal behavior (Becker, 1968, p. 207). The often quoted microeconomic foundation of his supply of offenses based on the von Neumann-Morgenstern concept of expected utility was developed in a series of footnotes (see Becker, 1968, pp. 177-203)

5 Cohen and Simpson (1997; quotation found in Rupp, 2008, p. 6) have a simple but sufficient explanation for non-economic readers: 'Utility is nothing more than an economist's jargon to represent the personal satisfaction one receives from various pecuniary and nonpecuniary pleasures in life'.
} 
the illegal action, $U_{C}$, would be 3 Euros, whereas the expected fine was 2 Euros. Hence the risk-neutral rational 'offender' would decide against putting a coin into the parking meter and in favor of the illegal alternative. Of course, such reasoning may be ambiguous in case of riskpreference, and, as mentioned above, it requires that a non-empty subgroup is complying according to rational choice rules, i.e. a significant number of people neither belong to the group of always strictly norm-abiding citizens nor to the group of never law-abiding individuals. Thus, summarizing the standard rational choice reasoning covered in equation (2), deterrence would not work when either the certainty of a sanction is zero, or when sanctions lack severity. In both cases, the product $p C_{C}$ would be zero, i.e. there would be no credible threat from expected sanctions for wrongdoing.

Equation (2) also represents the basic foundation of Becker's so-called 'supply of offenses', which is grounded on first-order conditions of the difference between illegal and legal sources of expected utility, $E_{C}-E_{N C}$. Taking derivatives with respect to the crucial impacting factors $\mathrm{p}, C_{C}$ and $E_{N C}$ yields the behavioral equation

$$
C=C\left(\underset{(-)}{p}, \underset{(-)}{C_{C}}, \underset{(-)}{E_{N C}}, X\right) .
$$

Thus, under standard neoclassical assumptions (see Becker, 1968, for details), crime (C) would fall when the probability of detection and punishment increases, or when potential offenders face the risk of higher costs from committing crimes. These disincentives to crime change in response to longer or tougher prison sentences, for example in terms of tough-oncrime policies such as the Californian 'three-strikes' law (see, e.g., Helland and Tabarrok, 2007, on costs and benefits of this policy), or the application of adult criminal law instead of juvenile criminal law (as discussed in Entorf, 2012). Crime would also decrease when utility from non-criminal activities, $E_{N C}$, increases, for instance because of lower unemployment risk (see Raphael and Winter-Ebmer, 2001; Lin, 2008; among others), or improving current and future legal income opportunities, which include the broad and lasting impact of education on crime (Lochner and Moretti, 2004; Machin et al., 2011). Of course, empirical models on crime would fail if only $p, C_{C}$ and $E_{N C}$ were included as explanatory factors of crime. Thus, $\mathrm{X}$ represents further factors of which age, gender, alcohol and drug addiction, migration background, race, peer influence, and family background belong to the (incomplete) list of variables often (but not regularly) found in crime studies. An indeterminacy of statistical tests of deterrence models is the rather arbitrary choice of $\mathrm{X}$. Indeed, a meta-study by Dölling et al. (2009, Table 5) reveals that the choice of control 
variables has a high influence on finding significance or non-significance of deterrence indicators in empirical studies: Dependent on the choice of the control variable, reported average t-values on deterrence variables range from -0.5 to -2.3 . The problem of ad-hoc specifications is discussed in more detail by Durlauf and Nagin (2010).

\section{On the impact of certainty.}

Early contributions. The first empirical tests of Becker's 'supply of offenses' model have been conducted in the late 60ies and early 70ies of the last century. Early studies by Tittle (1969), Ehrlich (1972) and Sjoquist (1973) have found significant crime reducing effects in response to increasing certainty $(p)$. However, these contributions were flawed by endogeneity problems and ignorance of incapacitation effects, as already pointed out by Nagin (1978), who gave the first literature survey on the validity of the deterrence hypothesis. Although Ehrlich (1973) and Car-Hill and Stern (1973) used two-stage least squares techniques to account for simultaneity problems, identifications strategies such as use of lagged endogenous variables would be considered problematic from the current viewpoint of modern econometrics (see also Durlauf and Nagin, 2010). Ehrlich's (1973) results were intensively discussed. For instance, Vandaele (1978), after detecting data errors, performed a replication study and some sensitivity analysis but more or less confirmed Ehrlich's results. However, not all studies agreed on the evidence in favor of the deterrence hypothesis. Brier and Fienberg (1980) discarded all empirical findings regarding the Becker-Ehrlich model. They argue that the model is too simplistic and empirical findings are not reliable enough to draw any conclusion in favor or against the deterrence hypothesis. According to Rupp (2008), this criticism seems to be exaggerated, but the ambiguity of Ehrlich's findings was and still is perhaps the main reason for the lasting debate on Ehrlich's problematic contribution to the deterrence literature.

Ehrlich's (1973) article also received prominent attention as a significant contribution to the theoretical literature. He modified Becker's theoretical model by using a time allocation model. This framework widens the perspective because it includes leisure time as a source of utility besides utility from time spent on legal and illegal activities. This makes theoretical predictions less clear than in Becker (1968), where utility is achieved either from illegal or from legal activities. Ehrlich (1973, p. 530, footnote 13) draws attention to the point that the unambiguous negative sign of deterrence effects only holds when individuals are risk-neutral or risk-averse (see also Block and Heineke, 1975, and Heineke, 1978, for a discussion of fixed 
versus flexible leisure time, and the interplay of substitution and income effects of varying the certainty of sanctions).

Survey of surveys and meta-studies. In the first three decades after Becker's (1968) seminal article, several surveys on the economics of crime have been published. Among this group, Nagin (1978), Brier and Fienberg (1980), Beyleveld (1980), Cameron (1988) and Eide et al. (1994) are prominent examples. Rupp (2008) summarizes all of them in more detail. During the last few years, the frequency and number of surveys seems to accelerate. Surveys by Rupp (2008), Donohue (2009), Apel and Nagin (2011), Ritchie (2011) and Durlauf and Nagin $(2010,2011)$, to name only a selection of remarkable new publications, confirm what has been found by earlier studies, i.e. that the deterrent effect of the certainty of sanctions far outweighs the severity of punishment.

Eide et al. (1994) is a good starting point in order to provide a sample of typical estimates of the deterrent effect of the certainty of sanctions. The authors summarize 20 international cross-sectional studies based on a variety of model specifications, types of data and regressions. They find the median value of the 118 elasticity estimates of crime rates with respect to various measures of the probability of punishment to be about -0.7 . The median of the somewhat fewer severity elasticities is about -0.4 .

Donohue (2009) focuses on the effect of the imprisonment rate in six studies based on aggregate data and finds that most studies show a negative effect of incarceration rates on crime. However, the estimates of the elasticity of crime range considerably between Levitt's (1996) result of -0.70 for robbery (using prison overcrowding litigations as an instrumental variable), and results by Liedka et al. (2006) on all index crimes which suggest that marginal imprisonments would even increase crime. Donohue (2009, p. 17) admits that his best guess for the elasticity is 'highly uncertain', most likely being between -0.10 and -0.15 but 'conceivably within the broader interval between -0.05 and -0.40'. Durlauf and Nagin (2010) discuss the papers of Donohue's survey at some length. They criticize the statistical methodology employed in these studies and dismiss Levitt (1996) as the sole author of the survey who convincingly addressed the simultaneous interdependencies between crime and imprisonment rates. A further problem of studies relying on the imprisonment rate as the sole indicator of $p$ is that it covers compound effects which might cause an omitted variable bias (see the subsequent subchapter on 'decomposing the certainty effect').

Durlauf and Nagin (2010) consider studies based on police manpower more persuasive than those based on imprisonment rates. Their sympathy seems to be affected by the highly 
influential discussion between Levitt $(1997,2002)$ and McCrary (2002) on the choice of meaningful instruments. Their finding of crime reducing effects from exogenous variations of police officers has been confirmed by Evans and Owens (2007), who use grants for hiring new police officers to create exogenous variation in the police size. Durlauf and Nagin (2010) summarize the findings from these studies and further replication studies and mention an average elasticity of -0.3 for most estimates relating total crimes and police presence. However, given the high dependency of results on the type of crime under consideration (see below), such 'typical' results covering the whole range of crime categories can hardly be considered useful for practical public policy purposes (which is in line with Donohue's 'uncertainty' about his best guess).

A recent extensive meta-analysis based on 700 empirical studies with 7,822 estimates of the crime preventing effect of general deterrence (certainty or severity of sanctions) by Rupp (2008; see also Dölling et al., 2009) reveals a large variation of effects depending on the choice of the deterrence variable. For instance, using the indicator 'ratio of convictions to reported crimes' produces a highly statistical evidence in favor of the certainty of sanctions (median t-value $=-3.5$ ), whereas using the clearance rate would produce less significant results (median-t-value $=-1.9$; Dölling et al., 2009, Table 3). Results also differ with respect to the crime category under consideration. Rupp (2008, Table 3.43, p. 126) finds that among the offenses which have been in best accordance with the deterrence hypothesis are speeding (median-t-value $=-2.2)$, tax evasion $(-2.1)$, severe theft $(-2.1)$, and fraud $(-2.0)$, whereas sexual assault (-0.5), manslaughter (0.0) and drug dealing (0.0) were only rarely found to be consistent with the deterrence hypothesis. Thus, very prominent in the group of consistent types of crimes are non-violent crimes, while the discordant part seems to incorporate violent crimes and drug-related offenses.

Decomposing the certainty effect. Testing the theoretical prediction of $p$, i.e. the certainty of sanction, requires empirical measurement of the joint probability of detection and subsequent punishment. Many empirical models are restricted to only one indicator such as clearance rates (Entorf and Spengler, 2000), number of police officers (Levitt, 1996) or imprisonment rates (Liedka et al., 2006). However, variations in clearance rates may not change the threat of expected sentences when prior to judicial decisions cases are dismissed or discharged by the public prosecutor. Moreover, expected sentences differ in response to court decisions, which can be dismissal ${ }^{6}$, unconditional imprisonment, probation, (financial) fine or other sanctions

\footnotetext{
${ }^{6}$ Even without formal convictions in a court, individuals may be deterred through the threat of internalized social norms, i.e. shame and stigma (known as 'informal deterrence' in criminology; see Wenzel, 2004).
} 
such as educational measures. Thus, to improve the consistency of empirical models with their theoretical counterparts and in order to analyze the effectiveness of the various sources of deterrence, it is necessary to decompose the certainty effect $p$ into its components. In its simplest way, this can be done by distinguishing between the probability of detection (clearance rate), $p_{c l}$, and the conditional probability that a suspect is sentenced, $p_{s \mid c l}$ (probability of a sentence, conditional on detection), i.e.

$$
p=p_{c l} p_{s \mid c l}
$$

The variation of certainty effects becomes more transparent when changes in clearance or arrest rates are separated from the ones of courts and sentences. In Germany, for instance, the portion of crime suspects formally convicted in a court (under general and juvenile penal law) steadily declined from 64\% in 1981 to $42 \%$ in 2008 (Heinz, 2010, p.50). To fully understand such variations, changes in $p_{s \mid c l}$ can be further decomposed into changes of the indictment rate (driven by public prosecution), $p_{\text {court|cl }}$ (i.e. the probability that a suspect is brought to court), and those stemming from court decisions, $p_{\text {s|court }}$ (i.e. the probability that a suspect is convicted, given he or she is brought to court), eventually leading to $p_{s \mid c l}=p_{\text {court|cl }} p_{s \mid c o u r t}$. In both the U.S. and European legal systems, the (high) discretionary power of the prosecutor is to determine which case should be disposed of before trial by either dismissal of the charges, or by imposing certain obligations on suspects in exchange for laying the file aside. Again referring to the German example, Entorf (2011) reports that prior to judicial decisions, a growing share of cases has already been discharged by the public prosecutor. In 2008, prosecutors were responsible for $87 \%$ of all dismissals in Germany (and judges in courts only ordered the remaining 13\%), whereas this share was still at 67\% in 1981 (Entorf 2011, Table 1). Thus, to summarize, the relative importance of police, public prosecution and judges ${ }^{7}$ can dramatically change over time.

The picture is still incomplete unless the risk of the most severe outcome conditional on detection has been covered, i.e. the certainty of an (unconditional) prison sentence. After

\footnotetext{
${ }^{7}$ In Germany, the time series variance of $p$ is mainly driven by public prosecution. Covering evidence for the period 1980 through 2008, Entorf (2011, Table 2) report that the share of convictions of suspects brought to court is pretty stable over time, with minima and maxima ranging between $81.3 \%$ in 1990 and $83.7 \%$ in 2000 .
} 
including $p_{\text {pris|s }}$, i.e. the probability of imprisonment given a conviction, the full ${ }^{8}$ decomposition of the probability of imprisonment (conditional on detection) looks as follows:

$$
p_{\text {pris } \mid c l}=p p_{\text {pris } \mid \mathrm{s}}=p_{c l} p_{\text {court|cl }} p_{\text {s|court }} p_{\text {pris } \mid s}
$$

Not surprisingly, empirical indicators of $p_{\text {pris|cl }}$ vary across time and space. ${ }^{9}$

Reasonable public policy analysis and recommendations should take the role of all key players and their decisions, i.e. interplay of police, prosecutors and courts, representing the law enforcement system (Van Tulder and Van der Torre, 1999), into account. Only few studies also cover the risk of convictions, e.g. by the ratio of convictions to arrests. Among these exceptions are the early papers by Sjoquist (1973), Carr-Hill and Stern (1973), and Wolpin (1978) based on regional cross-sectional data. Cornwell and Trumbull (1994, their approach was replicated by Baltagi, 2006), who were among the first applying panel econometrics for testing general deterrence models, present exceptional work because of their comprehensive list of law enforcement variables containing the probabilities of arrest, conviction (conditional on arrest), and imprisonment (conditional on conviction) as well as the severity of sanctions. However, the overall impression is that only few studies are taking account of a comprehensive list of factors, something that is also pointed out by Mustard (2003) as well as Mendes and McDonald (2001).

In particular, the interplay of conviction rates and sentence lengths, i.e. the essential components of certainty and expected severity of punishment, has been neglected. However, it is obvious that components of general deterrence do not work independently of each other. Missing factors of the law enforcement system might cause severe omitted variable biases. ${ }^{10}$ Econometric evidence provided by Entorf (2011, Tables 5 and 6) reveals that the impact of

\footnotetext{
${ }^{8}$ Correctly speaking, the empirical measurement of $p$ would also require that the crime is reported to the police.

${ }^{9}$ Entorf and Spengler (2008, Table 2), e.g., report high regional imbalances between expected sentences in the northern state Schleswig-Holstein and the southern state Bavaria. Taking robbery as an example, in SchleswigHolstein the rate of convictions leading to unconditional imprisonment dropped from an average value of $64.2 \%$ for the time period 1977 to 1990 down to $48.0 \%$ for the period 1991 to 2001 . Comparing the same two time periods, this rate was rather stable in Bavaria: it slightly decreased from $72.6 \%$ down to $63.5 \%$. When looking at corresponding expected sentences (i.e $p_{\text {pris|cl }} \times$ average sentence length), the difference is even more pronounced: It decreased from 5.4 months to 4.9 months in Bavaria and plummeted from 4.3 months to only 2.4 months in Schleswig-Holstein.

${ }^{10}$ It is not surprising that in meta-studies (Dölling et al., 2009, see above) combined effects such as the ratio of convictions to reported crimes, i.e. $p_{s \mid c l}$, give different average effects than the clearance rate $p_{c l}$. However, the meta-analysis does not cover any systematic analysis of permutations and combinations of interacting deterrence variables.
} 
police $\left(p_{c l}\right)$ may be downward biased when variations of $p$ stemming from changing conviction rates are not covered in the econometric specification.

\section{On the impact of severity.}

Death penalty. The severity of punishment is the fundamental idea of capital punishment: 'if rational people fear death more than other punishment, the death penalty should have the greatest deterrent effect' (Ehrlich 1977, quotation found in Rupp, 2008, p. 22). Although this statement is questionable, either because the expected sentence would be nil when there would be no (perceived) risk of detection or because 'rational' suicide bombers expect going to paradise with the infamous seventy-two virgins ${ }^{11}$, the focus of most studies in the aftermath of Ehrlich (1975) lies on the absolute deterrent effect of capital punishment. Most publications refer to U.S. evidence, as can be seen from the fact that 71 out of 82 studies evaluated by Rupp (2008, p.22) use U.S. data, and 5 are based on Canadian data. Ehrlich's $(1975,1977)$ articles have fueled an ongoing debate about the effectiveness of the death penalty. His results have been criticized for data errors, misspecification problems, and other methodological problems (see Layson, 1985, for a survey). Numerous subsequent studies have rejected but also confirmed significance of the death penalty. For instance, Ehrlich and Brower (1987) reevaluated Ehrlich's original time series data and confirmed his previous results. Donohue and Wolfers (2005) summarize several studies on the death penalty in the United States. They conclude that all outcomes are too fragile and that the number of executions is too low to draw any noteworthy and robust conclusion. This result is in line with the meta-study on the significance of death penalties by Dölling et al. (2009, Table 10), where median $t$-values of effects range between -0.5 and +0.1 , i.e. below usual significance levels. This survey is not the right place to summarize all facets of the complex debate on the death penalty which is interesting for its methodological aspects, but which most scientists from industrialized countries outside the USA would not consider a practical and ethically tolerable alternative to lifelong sentences.

Evidence on the length of the prison sentence and prison conditions. According to the aforementioned meta-study (Dölling et al., 2009, Table 3), most results using the average length of served prison sentences as an indicator of the severity of sanctions do not show statistical significance (median $\mathrm{t}$-value $=-0.6$ ). This result is in line with the tenor of previous and recent surveys such as Eide et al. (1994), Durlauf and Nagin (2010, 2011) or Ritchie

\footnotetext{
${ }^{11}$ See Caplan (2006) for the relevance of rational-choice models for terrorism.
} 
(2011). However, Durlauf and Nagin (2010) correctly state that most effects are measured as marginal effects in addition to the already existing long sentence. Thus, more reliable evidence would be based on discontinuous jumps of severity. Levitt (1998) has found a significant drop in the offending of young adults when they reach the age of 18 , i.e. the age of jurisdiction for adult courts in Florida. Lee and McCrary (2009), who were able to measure the discontinuous change of majority in weeks and days instead of years (as in Levitt 1998), confirmed the negative sign but results were insignificant.

Other abrupt and unexpected changes of deterrence come from natural experiments. Maurin and Ouss (2009) and Drago et al. (2009) study the effect of external variations arising in response to collective pardons in France and Italy, respectively. Maurin and Ouss (2009) show that five years after release those who have received a reduced sentence as a consequence of the pardon had a $12 \%$ higher rate of recidivism than those who had received no reduction. In the case of the Italian clemency, inmates received a conditional reduction of prison sentences. In case of reoffending, they had to serve the remaining amount of their sentence (in addition to the new sentence). Drago et al. (2009) find that the threat of increased sanction continued after release: For every month the former prisoner would have to serve if convicted there was a $1.2 \%$ reduction in the propensity to recommit crimes. Both studies touch the problem of 'specific deterrence', i.e. whether individuals would avoid future imprisonment because they are deterred by their own previous sentencing experience. However, in particular the study by Maurin and Ouss (2009) also tests the deterrent effects of longer prison sentences, though based on a subgroup of former inmates. In the case of Drago et al. (2009), the effect is a combination of certainty and severity because the threat of serving the remaining sentence also depends on the probability of detection and conviction.

Harshness of prison conditions could be a further indicator of severity. Again referring to the reoffending of former prisoners (and touching specific deterrence), Drago et al. (2011) conclude that prison severity does not reduce the probability of recidivism; the estimates rather suggest that harsh prison conditions increase post-release criminal activity. Entorf (2012) analyzes expected recidivism rates of inmates aged between 18 and 21, who have been convicted either under adult criminal law or under juvenile jurisdiction. Results indicate that those treated under the more lenient juvenile law show a higher (subjective) probability of recidivism. Thus, this result is more in line with Levitt (1998) and Maurin and Ouss (2009), though based on different groups of (potential) offenders. 


\section{Limitations and extensions of the classical deterrence model.}

Predictions of the fundamental model (as presented in Chapter 2) are based on a static model under regular neoclassical assumptions. The classical rational choice model needs to be reconsidered in the face of challenging recent findings of behavioral economics. In particular, the (objective) detection probability and the disutility from punishment need to be adjusted given insights from prospect theory, myopia and dynamic deterrence:

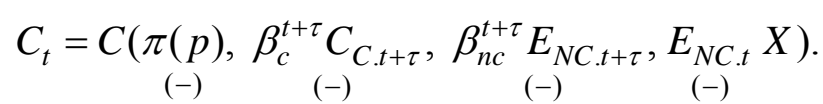

The new elements of a 'behavioral supply of offenses model' (equation 6) will be discussed below. Criminological research suggests that offenders have unusually high discount rates, i.e. they place high value on immediate utility gains, whereas future events are strongly discounted, i.e. they consider them as less important for current decisions than non-criminals. As consequences of criminal activities, if any, would have to be faced at some unknown time in the future, this so-called present bias (also called impulsiveness or myopia) leads to underestimation of expected future costs from punishment, $C_{C . t+\tau}$ (see, e.g., Jolls et al., 1998; Lee and McCrary, 2009). In particular, adolescence, alcohol or drug misuse (not to mention mental impairment) may lead to a very small personal weight of future consequences, i.e. $\beta_{c}<<1^{12}$. McAdams (2011) discusses the importance of the present bias for the general deterrence of crime. For instance, to create deterrence despite a significant present bias, 'one must either make the deferred costs of crime immediate or make the immediate benefits of crime deferred' (McAdams, 2011, p.101). For this reason, the perceived timing of arrests needs to be as close as possible to the commission of a crime.

The classical static deterrence model also neglects future consequences of illegal activities which a rational forward-looking individual would take into account. Given the person will be detected and punished, she would expect diminished re-employment chances, reductions in social capital, relational problems, etc. Thus, rational individuals would also be deterred by the potential future reduction of expected legal utility gains, i.e. shrinking $E_{N C . t+\tau}$, in response to the stigma of a criminal record (see Rasmusen, 1996; Funk, 2004). This potential threat is also called ‘dynamic deterrence’ (Imai and Krishna, 2004).

\footnotetext{
${ }^{12}$ In economic literature, the present bias is often treated in terms of a special functional form called hyperbolic discounting. Hyperbolic discount rates refer to a functional form where early delays diminish the present value much more than later delays (see Frederick, 2002, for details).
} 
A related but different deviation from classical rational choice and general deterrence models is the existence of subjective probabilities of detection and punishment, $\pi(p)$. These should be more precisely called decision weights because they do not satisfy the classical probability axioms. Allais (1953) was the first who criticized expected utility theory for its inconsiderate use of objective probabilities, i.e. $\pi(p)=p$, in models of human behavior. Kahneman and Tversky (1979) developed an alternative model called prospect theory. They emphasized that '... people are limited in their ability to comprehend and evaluate extreme probabilities, highly unlikely events are either ignored or overweighted [...] Consequently, $\pi$ is not wellbehaved near the end-points' (Kahneman and Tversky, 1979, pp. 282, 283). Experiments show that individuals overweight low probabilities of gains, i.e. $(1-\pi(p))>(1-p)$ in case of criminal gains, which implies $\pi(p)<p$, i.e. underweighting the risk of being caught and punished. The overestimation of the criminals' own ability to avoid any apprehension and sanction is also known as "overconfidence" in the behavioral economics literature (McAdams and Ulen, 2009).

The perceived risk of detection of re-offenders is of particular importance because of the high share of crimes committed by recidivists. Stafford and Ward (1993) argue that the probability of re-offending needs to be considered conditional on recent experiences of punishment avoidance. Successful punishment avoidance would reduce the perceived probability of being punished. Piquero and Pogarsky (2002) argue that criminals behave according to the belief that 'lightning won't strike twice' (Jacobs, 2010, p. 419; found in Ritchie, 2011; also known as the 'gambler's fallacy' effect): They underestimate the probability of being detected and convicted, because they (erroneously) believe that the risk of being punished again is very low. Some further details and discussions on the 'perceived' (instead of objective) risk of being punished can be found in Kleck et al. (2005), Apel and Nagin (2011), McAdams and Ulen (2009) and Ritchie (2011).

\section{The threat of punishment when trust in criminal law is absent.}

One of the stylized facts in empirical criminological research is that offenders are more likely than non-offenders to be victims, and victims are more likely than non-victims to be offenders. ${ }^{13}$ A prominent explanation of the victim-offender overlap is the subculture-of-

\footnotetext{
${ }^{13}$ According to a survey provided by Shaffer (2004), results in the literature indicate that offenders are 1.5 to 7 times more likely than non-offenders to be victims, and victims are 2 to 7 times more likely than non-victims to be offenders.
} 
violence approach (Singer, 1981), according to which individuals who attack others risk retaliations from former victims. Rational choice theory seems to be generally questioned by such 'irrational' retaliatory behavior of victims and criminals. However, retaliation can be seen as a rational deterrence strategy in a 'pre-legal', 'pre-societal' or 'natural state" (Hume, 1739) community. Given lacking access or trust in the public institution of criminal law systems in modern societies, victims might be tempted to take the law in their own hands. In particular in disadvantaged neighborhoods and subcultural societies where the retaliatory ethic of the 'code of the street' (Anderson, 1999) is used in lieu of criminal codes, the credible threat of punishing by strong retaliation might deter potential future perpetrators. 'Rational retaliation' would imply that the deterrent signal to the subsociety can be (random) redirection to the detriment of any available victim within a close microstructural or relational space: Would-be violators may be deterred even though they would not suffer any direct punishment (Jacobs and Wright, 2010). Sobel and Osoba (2009) argue that youth gangs form in response to government's failure to protect youths against violence. Indeed, their empirical results based on gang membership data suggest that the effect of gangs is to reduce the level of violence (contradicting Peterson et al., 2004).

Rational choice models are often criticized because they ignore that cognitive restrictions and emotional factors such as time pressure, peer group influence or anger restrict the long-run 'optimality' of individual decisions. As regards the overlap of victimization and offending, anger seems to be the major motivation of retaliatory behavior, as also stressed by many criminological and psychological research papers (see, e.g., Agnew, 1992, Kubrin and Weitzer, 2003, Jacobs and Wright, 2010, Simons and Burt, 2011). Anger in response to perpetrated injury, frustration and unfair treatment can be a triggering event that motivates 'striking back', not necessarily to the perpetrator himself but also to non-involved bystanders and other available victims, also at some later point in time. Such behavior is often the consequence and origin of norms of honor and respect (or fear of dishonor and shame, respectively), prevailing and potentially escalating in subcultural societies (Anderson 1999, Kubrin and Weitzer, 2003), and serving as a deterrent factor when trust in criminal justice systems is absent. Such retaliatory behavior is not restricted to deprived subgroups: As suggested by findings in Fehr and Gächter (2002), punishing 'unkind' behavior of others or 'negative reciprocity' seems to be a social norm rooted in general human behavior. Participants in their experiments revealed some 'altruistic punishment' behavior, i.e. they punished defectors even when they had costly disadvantages from the retaliation. This socalled pro-social behavior has its origin in the notion of fairness as can be seen from the outcome of many ultimatum-game experiments: Responders often destroy any portion of their (guaranteed) gains when they perceive the proposal of the proposer as unfairly low. Thus, anger about unfair treatment is the individual motivation, but its social effect could be deterrence. 


\section{Conclusions and future research.}

Certainty and severity of sanctions form the two cornerstones of general deterrence. This survey reveals that its underlying classical rational choice theory has been reconsidered by recent research, yielding important insights from bounded rationality and behavioral economics. Future research will continue to analyze the threat of punishment, but the focus will be on the role of hyperbolic discounting, overconfidence, perceived risk, ambiguity, prospect theory, and dynamic models, just to name only a few of many interesting fields. Also the empirical approach has changed dramatically during the last ten years or so. Modern criminological research is often based on laboratory and (quasi) natural experiments (such as changes in legislation or clemencies) which create convincing external variations of deterrence variables. ${ }^{14}$ From a criminal policy point of view, the problem of cost-efficient use of deterrence instruments has a high potential for future research. Given the relatively small effect coming from the severity of sanctions one might be tempted to shift resources from imprisonment to policing, as proposed and discussed by Durlauf and Nagin (2011). Though certainly high on the political agenda, one should nevertheless be aware of the limited empirical evidence (mostly coming from the U.S., and dealing with marginal effects of already long sentences). Moreover, alternative (long-run) cost-benefit considerations such as shifting scarce resources to education and families should be taken into account, since both poor education and family background are identified as the major reasons of lacking legal opportunities over the life cycle and resulting criminal careers.

\section{Bibliography}

Agnew, R. 1992. Foundation for a General Strain Theory. Criminology 30 (1):47-87.

Allais, M. 1953. Le Comportement de l'Homme Rationnel devant le Risque, Critique des Postulats et Axiomes de l'Ecole Americaine. Econometrica 21:503-546.

Anderson, E. 1999. Code of the Street. New York: Norton.

Apel, R., and D.S. Nagin 2011. General deterrence: A review of recent evidence. In J. Q. Wilson and J. Petersilia (Eds.). Crime and Public Policy 4:411-436. New York: Oxford University Press.

Baltagi, B.H. 2006. Estimating an Economic Model of Crime Using Panel Data from North Carolina, Replication Study. Journal of Applied Econometrics, 21(4), 543-547.

Beccaria, C. B. 1819. Of Crimes and Punishment. Heward, Robert, London. Published 1764 in Italian.

Becker, G. 1968. Crime and Punishment: An Economic Analysis. Journal of Political Economy 78 (2):169-217.

Bentham, J. 1830. The Rationale of Punishment. Nicklin, Philip H., Philadelphia, Written in the 1770s.

Bentham, J. 1781. An Introduction to the Principles of Morals and Legislation. Batoche Books, Kitchener 2000, http://socserv.mcmaster.ca/econ/ugcm/3113/bentham/ morals.pdf, (13 April 2011).

\footnotetext{
${ }^{14}$ See the contributions in Part III of the Handbook of Quantitative Criminology, edited by Piquero and Weisburd (2010), for further details on experimental methods and quasi-experimental design in criminology.
} 
Beyleveld, D. 1980. A Bibliography on General Deterrence. Saxon House, Teakfield Limited, Westmead.

Block, M. K. and J. M. Heineke. 1975. A Labor Theoretic Analysis of the Criminal Choice. American Economic Review 65 (3):314-325.

Brier, S. S., and S. E. Fienberg. 1980. Recent Econometric Modeling of Crime and Punishment. Support for the Deterrence Hypothesis? Evaluation Review 4 (2):147-191.

Cameron, S. 1988. The Economics of Crime Deterrence: A Survey of Theory and Evidence. Kyklos 41 (2):301-323.

Caplan, B. 2006. Terrorism: The Relevance of the Rational Choice Model. Public Choice 128:91-107.

Carr-Hill, R.A., and H. Stern. 1973. An Econometric Model of the Supply and Control of Recorded Offenses in England and Wales. Journal of Public Economics 2:289-318.

Chadwick, E. 1829. Preventive Police. London Review 1:252-308.

Cohen, M. A. and S. S. Simpson. 1997. Corporate Criminal Liability. in W. S. Lofquist, M. A. Cohen, and G. Rabe (eds.), Debating Corporate Crime. Anderson Publishing and Academy of Criminal Justice Sciences 2, Cincinnati.

Cornwell, C., and W. N. Trumbull. 1994. Estimating the Economic Model of Crime with Panel Data. Review of Economics and Statistics 76(2):360-366.

Dölling, D., H. Entorf, D. Hermann, and T. Rupp. 2009. Is Deterrence Effective? Results of a MetaAnalysis of Punishment. European Journal on Criminal Policy and Research 15:201-224.

Donohue, J. 2009. Assessing the Relative Benefits of Incarceration: The Overall Change Over the Previous Decades and the Benefits on the Margin. In Do Prisons Make Us Safer? The Benefits and Costs of the Prison Boom, S. Raphael, and M. Stoll, (eds). New York: Russell Sage Foundation Publications.

Donohue, J. J., and J. Wolfers. 2005. Uses and Abuses of Empirical Evidence in the Death Penalty Debate. Stanford Law Review 58 (3):791-845.

Drago, F., R. Galbiati, and P. Vertova. 2011. Prison conditions and recidivism. American Law and Economics Review 13:103-130.

Drago, F., R. Galbiati, and P. Vertova. 2009. The Deterrent Effects of Prison: Evidence from a Natural Experiment. Journal of Political Economy 117 (2): 257-280.

Durlauf, S. N., and D. S. Nagin. 2011. Imprisonment and Crime: Can Both Be Reduced? Criminology and Public Policy 10 (1):13-54.

Durlauf, S. N., and D. S. Nagin. 2010. The Deterrent Effect of Imprisonment. National Bureau of Economic Research working paper. http://www.nber.org/confer/2010/CRIs10/Durlauf_Nagin. pdf.

Ehrlich, I. 1977. Capital Punishment and Deterrence: Some Further Thoughts and Additional Evidence. Journal of Political Economy 85 (4):741-788.

Ehrlich, I. 1975. The Deterrent Effect of Capital Punishment: A Question of Life and Death. American Economic Review 65 (3):397-417.

Ehrlich, I. 1973. Participation in Illegitimate Activities: A Theoretical and Empirical Investigation. Journal of Political Economy 81:521-65.

Ehrlich, I. 1972. The Deterrent Effect of Criminal Law Enforcement. Journal of Legal Studies 1 (2):259-276.

Ehrlich, I., and G. D. Brower. 1987. On The Issue of Causality in the Economic Model of Crime and Law Enforcement: Some Theoretical Considerations and Experimental Evidence. American Economic Review 77 (2):99-106. 
Eide, E., J. Aasness, and T. Skjerpen. 1994. Economics of Crime: Deterrence and the Rational Offender.

Entorf, H. 2012. Expected Recidivism among Young Offenders: Comparing Specific Deterrence under Juvenile and Adult Criminal Law, forthcoming in European Journal of Political Economy. Previous version published as IZA Paper No 5434.

Entorf, H. 2011. Crime, Prosecutors, and the Certainty of Convictions. IZA DP No 5670.

Entorf, H., and H. Spengler. 2008. Is Being 'Soft on Crime' the Solution to Rising Crime Rates? Evidence from Germany. Discussion Papers of DIW Berlin 837, DIW Berlin, German Institute for Economic Research.

Entorf, H., and H. Spengler. 2000. Socioeconomic and Demographic Factors of Crime in Germany: Evidence from Panel Data of the German States. International Review of Law and Economics 20 (1): 75-106.

Evans, W., and E. Owens. 2007. COPS and Crime. Journal of Public Economics 91:181-201.

Fattah, E. A. (1983). A Critique of Deterrence Research With Particular Reference To The EconomicApproach. Canadian Journal of Criminology-Revue Canadienne de Criminologie 25 (1):79-90.

Fehr, E., and S. Gächter. (2002). Altruistic Punishment in Humans. Nature 45:137-140.

Frederick, S., Loewenstein, G., and T. O'Donoghue. 2002. Time Discounting and Time Preference: A Critical Review. Journal of Economic Literature 40 (2):351-401.

Funk, P. 2004. On the Effective Use of Stigma as a Crime-Deterrent. European Economic Review 48 (4):715-728.

Genn, H. 2010. Judging Civil Justice. Cambridge University Press.

Heineke, J. M. 1978. Economic Models of Criminal Behaviour. North Holland Publishing Company, Amsterdam.

Heinz, W. 2010. Das strafrechtliche Sanktionensystem und die Sanktionspraxis in Deutschland 1882 2008. Stand: Berichtsjahr 2008. Version: 1/2010. University of Konstanz. Online publication: http://www.uni-konstanz.de/rtf/kis/ Sanktionierungspraxis-in-Deutschland-Stand-2008.pdf.

Helland, E., and A. Tabarrok. 2007. Does Three Strikes Deter? A Nonparametric Estimation. Journal of Human Resources 42:309-330.

Hume, D. 1978. A Treatise of Human Nature. Oxford: Oxford Clarendon Press (original published in 1739).

Imai, S., and K. Krishna. 2004. Employment, Deterrence, and Crime in a Dynamic Model. International Economic Review 45:845-872.

Jacobs, B. 2010. Deterrence and Deterrability. Criminology 48 (2):417-441.

Jacobs, B. A., and R. Wright. 2010. Bounded Rationality, Retaliation, and the Spread of Urban Violence. Journal of Interpersonal Violence 25 (10):1739-1766.

Jolls, C., C. R. Sunstein, and R. Thaler. 1998. A Behavioral Approach to Law and Economics. Stanford Law Review 50:1471-1550.

Kahneman, D., and A. Tversky. 1979. Prospect Theory: An Analysis of Decision under Risk. Econometrica 47 (2):263-292.

Kleck, G., B. Sever, S. Li, and M. Gertz. 2005. The Missing Link in General Deterrence Research. Criminology 43 (3):623-660.

Kubrin, C. E., and R. Weitzer. 2003. Retaliatory Homicide: Concentrated Disadvantage and Neighborhood Culture. Social Problems 50 (2):157-180. 
Layson, S. K. 1985. Homicide and Deterrence: A Reexamination of the United States Time-Series Evidence. Southern Economic Journal 52 (1):68-89.

Lee, D. S. and J. McCrary (2009). The Deterrence Effect of Prison: Dynamic Theory and Evidence. Princeton University Centre for Economic Policy Studies, Working Paper no. 189. $<$ http://www.princeton.edu/ ceps/workingpapers/189lee.pdf>.

Levitt, S. 2002. Using Electoral Cycles in Police Hiring to Estimate the Effect of Police on Crime: Reply. American Economic Review 92 (4):1244-1250.

Levitt, S. 1998. Juvenile Crime and Punishment. Journal of Political Economy 106 (6):1156-1185.

Levitt, S. 1997. Using Electoral Cycles in Police Hiring to Estimate the Effect of Police on Crime. American Economic Review 87:270-290.

Levitt, S. 1996. The Effect of Prison Population Size on Crime Rates: Evidence from Prison Overcrowding Legislation. Quarterly Journal of Economics 111:319-352.

Liedka, R., A. Piehl, and B. Useem. 2006. The Crime-Control Effect of Incarceration: Does Scale Matter? Criminology and Public Policy 5:245-276.

Lin, M.-J. 2008. Does Unemployment Increase Crime? Evidence from U.S. Data 1974 - 2000. Journal of Human Resources 43 (2):413-436.

Lochner, L., and E. Moretti. 2004. The Effect of Education on Crime: Evidence from Prison Inmates, Arrests, and Self-Reports. American Economic Review 94 (1):155-189.

Machin, S., O. Marie, and S. Vujić. 2011. The Crime Reducing Effect of Education. Economic Journal 121:463-484.

Maurin, E., and A. Ouss. 2009. Sentence Reductions and Recidivism: Lessons from the Bastille Day Quasi Experiment. IZA Discussion Paper 3990.

McAdams, R.H. 2011. Present Bias and Criminal Law. John M. Olin Law and Economics Working Paper No. 562, The Law School, The University of Chicago.

McAdams, R.H., and T.S. Ulen. 2009. Behavioral Criminal Law and Economics, in Criminal Law and Economics: Encyclopedia of Law and Economics. N. Garoupa (ed.). 2nd ed., Massachusetts: Edward Elgar.

McCrary, J. 2002. Using Electoral Cycles in Police Hiring to Estimate the Effect of Police on Crime: Comment. American Economic Review 92 (4):1236-1243.

Mendes, S. M., and M. D. McDonald 2001. Putting Severity of Punishment Back in the Deterrence Package. Policy Studies Journal 29 (4):588-610.

Mustard, D. B. 2003. Reexamining Criminal Behavior: The Importance of Omitted Variable Bias. The Review of Economics and Statistics 85 (1):205-211.

Nagin, D., and R. Paternoster. 1993. Enduring Individual Differences and Rational Choice Theories of Crime. Law and Society Review 27:467-498.

Nagin, D. 1978. General Deterrence: A Review of the Empirical Evidence. In Deterrence and Incapacitation: Estimating the Effects of Criminal Sanctions on Crime Rates. A. Blumstein, J. Cohen, and D. Nagin. (eds.) Washington, DC: National Academies Press.

Peterson, D., T.J. Taylor, and F.-A. Esbensen. 2004. Gang Membership and Violent Victimization, Justice Quarterly 21 (4):793-815.

Piquero, A. R., and G. Pogarsky. 2002. Beyond Stafford and Warr's Reconceptualization of Deterrence: Personal and Vicarious Experiences, Impulsivity, and Offending Behavior. Journal of Research in Crime and Delinquence 39 (2):153-186.

Piquero, A. R., and D. Weisburd. 2010. (eds.) Handbook of Quantitative Criminology. New York: Springer. 
Pogarsky, G. 2002. Identifying "Deterrable" Offenders: Implications for Research on Deterrence. Justice Quarterly 19 (3):431-452.

Raphael, S. and R. Winter-Ebmer. 2001. Identifying the Effect of Unemployment on Crime. Journal of Law and Economics 44 (1):259-283.

Rasmusen, E. 1996. Stigma and Self-Fulfilling Expectations of Criminality. Journal of Law and Economics 39 (2):519-543.

Ritchie, D. 2011. Sentencing Matters. Does Imprisonment Deter? A Review of the Evidence. Melbourne.

Rupp, T. 2008. Meta Analysis of Crime and Deterrence. A Comprehensive Review of the Literature. Dissertation, Technische Universität Darmstadt. http://tubiblio.ulb.tu-darmstadt.de/38503/ (19 March 2012).

Shaffer, J.N. (2004). The Victim-Offender Overlap: Specifying the Role of Peer Groups, U.S. Department of Justice Report Document No 205126, also thesis at The Pennsylvania State University December 2003.

Simon, H. A. 1957. Models of Man, Social and Rational: Mathematical Essays on Rational Human Behavior in a Social Setting, New York: Wiley.

Simons, R. L., and C. H. Burt. 2011. Learning to be Bad: Adverse Social Conditions, Social Schemas and Crime, Criminology 49 (2):553-598.

Singer, S. 1981. Homogeneous victim-offender populations: A review and some research implications, Journal of Criminal Law and Criminology 72:779-788.

Sjoquist, D. 1973. Property Crime and Economic Behavior: Some Empirical Results. American Economic Review 63:439-446.

Sobel, R. S., and B. J. Osoba. 2009. Youth Gangs as Pseudo-Governments: Implications for Violent Crime, Southern Economic Journal 75 (4):996-1018.

Stafford, M. C. and M. Warr. 1993. A Reconceptualization of General and Specific Deterrence. Journal of Research in Crime and Delinquency 30 (2):123-135.

Thornburg, E. G. 2010. Saving Civil Justice: Judging Civil Justice. Book Review. Tulane Law Review $85: 247-267$.

Tittle, C. 1969. Crime Rates and Legal Sanctions. Social Forces 16:409-423.

Urban, L. S. 2009. Identifying "Deterrable" Offenders in a Sample of Active Juvenile Offenders Southwest Journal of Criminal Justice, 6 (1):79-99.

Vandaele, W. 1978. Participation in Illegitimate Activities: Ehrlich Revisited. In A. Blumstein, J. Cohen, and D. S. Nagin (eds.), Deterrence and Incapacitation: Estimating the Effects of Criminal Sanctions on Crime Rates, National Academy Press, Washington D.C., 270-335.

Van Tulder, F. and A. Van der Torre. 1999. Modeling Crime and the Law Enforcement System. International Review of Law and Economics, 19 (4):471-486.

Van Winden, F. and E. Ash. 2009. On the Behavioral Economics of Crime, paper was prepared for the workshop "Beyond the Economics of Crime", Heidelberg.

Wenzel, M. 2004. The Social Side of Sanctions: Personal and Social Norms as Moderators of Deterrence. Law and Human Behavior, 28 (5):547-567.

Wolpin, K. I. 1978. An Economic Analysis of Crime and Punishment in England and Wales, 18941967. Journal of Political Economy 86 (5):815-840. 